\title{
Assessment of Economic Efficiency in the State Support of Economic Innovation in Agriculture
}

\author{
Filippova S.P. \\ Department of Economics, \\ Management and Agricultural Consulting \\ Chuvash State Agricultural Academy \\ Cheboksary, Russia \\ Sveta-fp@mail.ru
}

\author{
Abrosimova M.S. \\ Department of Economics, \\ Management and Agricultural Consulting \\ Chuvash State Agricultural Academy \\ Cheboksary, Russia \\ amsik_74@mail.ru
}

\author{
Litvinova O.V \\ Department of Economics, \\ Management and Agricultural Consulting \\ Chuvash State Agricultural Academy \\ Cheboksary, Russia \\ lelja888@mail.ru
}

\begin{abstract}
Agriculture is a priority sector of the Russian economy. Focusing on the task of improving the living standards of the population and ensuring the country's food security, the State is constantly improving the tools of the state backing for agricultural goods producers, increasing budget funds for implementing government programs. It updates the issues of evaluating the effectiveness of subsidies and the efficient use of budget funds. Currently, in the field of agriculture the State seeks to support those entities which are implementing investment programs to modernize production and set innovations. According to the analysis of existing methods, effectiveness of the State influence on the innovative development of agriculture can be estimated by using various indicators. In most cases general outcome measures are offered, accumulating in themselves the effect of innovations or traditional indexes of effectiveness. However, for the practical purposes of evaluation and public administration, more specific indicators are required, taking into consideration both the features of the innovation process and the industry itself - agriculture. In the article proprietary technology for assessing the effectiveness of the State support measures for innovation processes is offered, it is based on the use of agricultural production innovative development indicators and benchmarks in the region and the technology is structured in its main priority areas. The presented technology will make it possible to assess the degree of innovativeness of the region's agricultural entities and to develop necessary measures for further development of the State support for innovation.
\end{abstract}

Keywords-agrobusiness; the State support; economic effectiveness; economic innovation; indicators.

\section{INTRODUCTION}

The modern development of the country's agro-industrial complex is impossible without the implementation of innovations. The situation in the agricultural sectors and the macro- and microeconomic trends studied by the authors in earlier works [2], [3], [4], [10] indicate that at the initial stage the State policy of stimulating and encouraging innovative activities of agricultural goods producers can play a positive role in enhancing innovation and investment processes in the agricultural sector. The increase in governmental spendings on innovative development of the agro-industrial sector necessitates the development of tools to assess their effectiveness and efficiency.

The question of the State support relative efficiency for innovation is rather controversial. Today foreign authors' empirical evidence of the State's support impact on the innovation process can be found [17]. But due to the small number of relevant analytical reports in Russia, we can only assume that in our country agricultural industry support tools (especially tax concessions) introduce positive alterations in the development of agricultural entities. As noted by individual authors, mainly medium and large agricultural organizations [8].

Evaluation of the State policy efficiency in the field of innovation is not carried out in Russia in comparison to the other industrial societies. Moreover there is no single methodology neither in research articles nor practical studies that can be used to conduct regular and independent assessments of the State innovation policy efficiency.

The efficiency of the State's influence on the innovative development of agriculture can be assessed by using various indicators. Most often, a number of typical indicators are used: production of agricultural goods per capita, level and quality of life, indicators of economic efficiency. These indicators are resultant and can testify the development of the innovation process in the agricultural sector only indirectly, in addition, 
- provides simplicity and clarity of interpretation of they do not allow to evaluate the innovative potential of this area.

To evaluate innovation policy, according to the authors, Dmitrik E.G., Vasilyeva E.N. it is necessary to develop a system of indicators rating the intensive factors of economic growth, based on signs of innovation [7]. They suggest to use the indicators based on the efficiency of the implementation of measures of the State innovation policy, such as: specific capitalized expenses of business entities in fixed assets, including buying of equipment and technologies, patenting, as well as the expenses on staff training and market research.

Petrushkina N.V., Rusyaeva Y.V. suggest methodology for calculating the efficiency of the State's expenses in agricultural sector based on the ratio of total budget support and its financial result [14]. But in this methodology, government expenditures are included as a whole and they are not divided by purpose.

Certain steps to use the methodology for assessing the efficiency of the State innovation policy were made in the Chuvash Republic in the framework of the republican target program "Innovative development - the basis of the competitiveness of the agro-industrial complex of the Chuvash Republic in 2010-2015 and for the period until 2020" implementation [1]. However, the analysis of the indicators used in the program showed that the suggesed approach also has certain disadvantages:

- selected factors of agriculture innovative development do not reflect all its significant directions;

- the results of the innovative activity certain parameters development are evaluated not by the level possible in practice, but only by randomly determined planning variable;

- there is no general integrated assessment of the innovation policy's efficiency.

\section{RESEARCH METHODOLOGY}

Based on the analysis of existing techniques reflected in the works of Prokofieva N.V., Petrova S.Y., Frolova O.A., Mukhina E., Gorokhova A. [5], [11], [13], [14], the authors suggest an improved version of the methodology for assessing the efficiency of the State's support measures for innovative processes in the region's agriculture. The algorithm for evaluating the efficiency of budget expenses to support innovation activity in agriculture is presented in Figure 1.

Implementation of the presented algorithm involves identifying priority areas of support for agricultural goods producers as part of ongoing state programs, the availability of a set of indicators reflecting the efficiency of budget expenses, the calculation of the integrating efficiency indicator and its subsequent comparison with the standard (normative indicator). The use of the standard has the following advantages:

- allows to get concise information about the efficiency of innovation policy in agriculture; indexes used to characterize a particular type of activity;

- allows to reduce the amount of information, increase its importance for decision-making process in areas of the State support for the innovative development of agriculture.

1. Identification and assessment of the size and structure of budget expenses to support the innovative development of agriculture.

2. Definition of indicators for assessing the efficiency of innovation

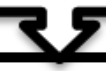

3. Expert identification of the standard level of the index for each selected indicator.

4. Determination of the weight value of each indicator in the overall efficiency index.

5. Determination of the overall integral indicator of efficiency and its interpretation.

6. Development of recommendations to improve the efficiency of innovation policy in agriculture in the region, making managerial decisions to adjust innovation policy

Fig. 1. algorithm of evaluating the efficiency of the state's support for innovative processes in agriculture

To assess the efficiency of measures of the State support for innovative processes, the authors suggest the following set of indicators:

1. Agricultural organizations financial state index, in percents - relative indicator characterizing the share of profitable agricultural organizations, in their total amount:

$$
\mathrm{I}_{\mathrm{F}}=\left(\mathrm{K}_{\mathrm{p}} / \mathrm{K}\right) * 100 \text {, }
$$

where: $\mathrm{I}_{\mathrm{F}}$ - index of financial status of agricultural

$K_{\mathrm{p}}$ - number of profitable agricultural organizations, ea;

$\mathrm{K}$ - total number of agricultural organizations, ea.

2. Index of implementation of selective breeding results, in percents - relative indicator characterizing the sup portability of agricultural goods producers with high-quality seeds.

It is calculated as the ratio of the area sown with elite seeds and seeds of I - IV reproduction of grain and leguminous crops to the total sown area of grain and leguminous crops:

$$
\mathrm{I}_{\mathrm{C}}=\left(\mathrm{N}_{\mathrm{c}} / \mathrm{N}\right) * 100
$$

where: $I_{c}$ - the unit weight of the area sown with elite seeds and seeds of I - IV reproduction, in the total sown area of grain and leguminous crops;

$\mathrm{N}_{\mathrm{c}}$ - the area sown with elite seeds and seeds of I - IV reproduction, in the total sown area of grain and leguminous crops, ha;

$\mathrm{N}$ - total sown area of grain and leguminous crops, ha. policy in the agricultural sector. organizations; 
where: $\mathrm{H}$ - intangible assets' average annual cost , million RUB.;

$A_{B}$ - capital assets’ average cost, million RUB.

9. Index of the energy-saturated equipment availability, in percents - relative indicator characterizing the share of energysaturated equipment in the total structure of agricultural organizations technical equipment:

$\mathrm{I}_{\mathrm{H}}=Э_{\mathrm{T}} / Э_{\mathrm{c}} * 100$

where: $Э_{\mathrm{T}}-$ the amount of energy-saturated equipment available in agricultural organizations, ea.;

$\ni_{c}$ - total amount of technical equipment available in agricultural organizations, ea.

10. Index of innovative projects implementation, in percents - relative indicator characterizing the level of agricultural organizations innovative activity.

It is determined by the ratio of the organizations number implementing innovative projects to the total number of agricultural organizations:

$$
\mathrm{I}_{\Pi}=\mathrm{K}_{\mathrm{\Pi}} / \mathrm{K} * 100
$$

where: $K_{п}$ - number of organizations implementing innovative projects, ea.;

$\mathrm{K}$ - total amount of agricultural organizations, ea.

The determination of each indicator standard value was carried out by experts. Thus, the levels of breeding achievements use and the genetic potential of farm animals should be $100 \%$ (100\% of the area should be sown with seeds of high reproduction), only in this case we can talk about the growth of agricultural organizations innovative activity, therefore, the standard value for this index equals 1 . The quality index of labor resources has a reference value of 0.2 or $20 \%$. The quality index of labor resources has a standard value of 0.2 or $20 \%$. There is a norm accepted in practice that managers and specialists of agricultural organizations should improve their skills every 5 years. The index of intangible assets use in the agro-industrial complex should approach $20 \%$ on average. According to the estimates of the Federal Institute for Certification and Valuation of Intellectual Property and Business (SOIS-SERVAL) in the Russian Federation the size of intangible assets in organizations varies between 12 and $23 \%$.

In the real sector of economy, the share of intangible assets varies from 20 to $25 \%$ of organizations assets total value [6]. In an innovative economy, most agricultural organizations must be profitable, which is consistent with the goals of innovation - improving production efficiency and business profitability. In general, most indicators should have a standard value close to 1 .

Suggested methodology, in addition to the standard value of indicators, involves taking into account their significance in the overall integral estimation of agricultural goods producers innovativeness. For example, the index of financial status has a lower weight number than the index of energy-saturated equipment. In this regard, for each index value a weight number was determined. The total weight number equals 1 . After identifying the weight number of the indexes, the comparative and total efficiency, the total integral coefficient 
is determined. The total integral index is the sum of the products of the comparative performance indicator for the selected indexes and the corresponding weight numbers. The total integral index is determined by the following formula:

$\mathrm{I}_{\mathrm{Q}}=\sum \mathrm{I}_{\mathrm{C} 1} * \mathrm{~m}_{1}+\mathrm{I}_{\mathrm{C} 2} * \mathrm{~m}_{3}+\ldots \ldots \mathrm{I}_{\mathrm{Cn}} * \mathrm{~m}_{\mathrm{n}}$

where: $\mathrm{I}_{\mathrm{Q}}$ - overall integrated performance index;

$\mathrm{I}_{\mathrm{C} 1,2 \ldots \mathrm{n}^{-}}$comparative index of effectiveness for selected indexes;

$\mathrm{m}_{1,2 \ldots \mathrm{n}}-$ weight number in comparable indexes of effectiveness.

The value of the total integral index should approach 1.

\section{RESULTS}

According to the suggested methodology, the authors evaluated the indexes in the Chuvash Republic for 2018 (table 1).

TABLE I. INDICATORS OF ECONOMIC EFFICIENCY OF THE STATE'S SUPPORT MEASURES OF INNOVATIVE PROCESSES IN AGRICULTURE OF THE CHUVASH REPUBLIC FOR 2018

\begin{tabular}{|c|c|c|c|c|c|}
\hline $\begin{array}{l}\text { The name of the assessment } \\
\text { index of innovative measures in } \\
\text { agriculture }\end{array}$ & 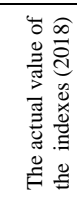 & 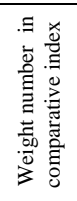 & 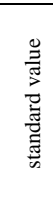 & 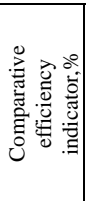 & 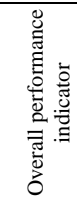 \\
\hline $\begin{array}{c}\text { Index of financial status of } \\
\text { agricultural organizations }\end{array}$ & 0,829 & 0,05 & 1 & 82,9 & 0,0414 \\
\hline $\begin{array}{l}\text { Implementation index of } \\
\text { selective breeding results }\end{array}$ & 0,28 & 0,12 & 1 & 28 & 0,0336 \\
\hline $\begin{array}{l}\text { The genetic potential index of } \\
\text { farm animals }\end{array}$ & 0,362 & 0,12 & 1 & 36,2 & 0,0434 \\
\hline Resource potential use index & 0,89 & 0,01 & 1 & 89 & 0,0089 \\
\hline Soil fertility index & 0,47 & 0,05 & 1 & 47 & 0,0235 \\
\hline $\begin{array}{l}\text { Index of physical quantity of } \\
\text { investments in fixed assets in } \\
\text { agriculture }\end{array}$ & 1,11 & 0,15 & $>1$ & 111,0 & 0,1665 \\
\hline Labor force quality index & 0,03 & 0,10 & 0,2 & 3 & 0,003 \\
\hline Index of use of intangible assets & 0,003 & 0,10 & 0,2 & 3 & 0,0003 \\
\hline $\begin{array}{l}\text { Index of the availability of } \\
\text { energy-saturated equipment }\end{array}$ & 0,21 & 0,15 & 1 & 21 & 0,0315 \\
\hline $\begin{array}{l}\text { Index of implementation of } \\
\text { innovative projects }\end{array}$ & 0,26 & 0,15 & 1 & 26 & 0,039 \\
\hline Integrated Efficiency Ratio & & 0,3911 \\
\hline
\end{tabular}

All-in-all, the value of the total integral index in the Chuvash Republic is 0.3911 , which is less than 1 . This indicates a lack of funds efficiency for innovative support to agriculture. The most problematic areas are the following - the use of intangible assets and labor resources, resource use index is low as well, which may be related to the problems of introducing organizational, managerial and technological innovations.

\section{DISCUSSION}

Summing up the research, we can conclude that the transition of agriculture to an innovative path of development in the present situation is impossible without a focused State policy to support innovative transformations in the agricultural sector. To improve the efficiency of budgetary funds and the State programs, methodologies and tools for evaluating the efficiency of implemented programmatic measures are required.

The methodology suggested by the authors, based on the calculation of private and integral indicators and their comparison with standard values, allows not only to evaluate the results and efficiency of the measures implemented, but also to design their projected values, which correspond with the principles of indicative planning. The results of the calculations can be used to redistribute budget funds according to priorities, taking into account relevance and efficiency, identify areas for improving the forms and methods of the State support for innovative activities of subjects of the real agricultural economy.

\section{CONCLUSIONS}

In general, the use of indexes in assessing the efficiency of measures of the State innovation policy, on the one hand, will determine the effectiveness of spending public funds. On the other hand, it will provide a visual assessment of innovative potential use level in the region's agriculture.

\section{References}

[1] Republican target program of the Ministry of Agriculture of the Chuvash Republic "Innovative development - the basis of competitiveness of the agro-industrial complex of the Chuvash Republic" for 2010-2015 and for the period until 2020. It is approved by the decision of the Government of the Chuvash Republic on June 4, 2010 No. 167.

[2] Abrosimova, M.S. State regulation of agricultural enterprises [Text] / M.S. Abrosimova, A.E. Makushev // The development of agricultural science as the most important condition for the effective functioning of the country's agro-industrial complex: Collection of materials of the AllRussian scientific and practical conference dedicated to the 70th birthday of Honored Worker of Higher School of the Chuvash Republic and the Russian Federation, Doctor of Veterinary Sciences, Professor Kirillov Nikolay Kirillovich, 2018, pp. 491-495.

[3] Vladimirov, V.V. Assessment of the efficiency of the state agricultural management system in the region [Text] / V.V. Vladimirov, S.P. Filippova // In the almanack: Scientific and educational environment as the basis for the development of the agro-industrial complex and social infrastructure of the village: materials of the international scientific-practical conference (dedicated to the 85th anniversary of the Federal State Budgetary Educational Institution of Higher Education "Chuvash State Agricultural Academy”). FSBEI of HE "Chuvash State Agricultural Academy", 2016, pp. 607-611.

[4] Vladimirov, V.V. Expert assessment of the effectiveness of the state agricultural management system based on an analysis of existing agribusiness conditions [Text] / V.V. Vladimirova, V.V. Belov, S.P. Filippova // News of the International Academy of Agricultural Education , 2017, № 33, pp. 51-58.

[5] Gorokhov, A. A model for assessing the effectiveness of agricultural financial support on the regional level [Text] /A. Gorokhov // Agribusiness : Economics and Management, 2011, № 10, pp. 70-73.

[6] Gunina, E.N. The role of intangible assets in the value of the enterprise [Text] / E.N. Gunina, A.A. Kazakov // International Research Magazine, 2015, № 8 (39) Part 1, pp. 30-32.

[7] Dmitrik, E.G. Directions of improving methods for assessing the effectiveness of the State innovation policy [Text] /E.G. Dmitrik, I. N. Vasilieva // Economic analysis: theory and practice, 2014, № 45 (396), pp. 44-49.

[8] Ivanova, D.A. The problem of assessing the effectiveness of public policy in the field of innovation support // Economics and management of innovative technologies, 2018, № 11 [electronic resource]. URL: http://ekonomika.snauka.ru/2018/11/16305 (date of the application: 08.02.2019)

[9] Kochergina S.G. Anasysis and evaluation of the innovative potential of the region / S.G. Kochergina // Bulletin of the Russian University of Cooperation, 2018, № 2 (32), pp. 55-59 
[14] Petrushkin, N.V. The effectiveness of certain areas of budget support for agricultural production in the region [Text] / N.V. Petrushkin, Y.V. Rusiaev // Regionology, 2010, № 1, pp. 108-116.

[10] [10] Litvinova, O.V. About improving the instruments of the State regulation of the agro-industrial complex [Text] / O.V. Litvinova, O.G. Vasilieva // Bulletin of the Russian University of Cooperation, 2016, № 4 (26), pp. 57-62.

[11] Mukhina, E. Assessment of the effectiveness of the state support for agricultural production [Text] /E. Mukhina// Экономист, 2007, № 4, pp. 89-93.

[12] On the results of the work of the agro-industrial complex of the Chuvash Republic for 2018 and tasks for the coming period [electronic resource]. URL:http://www.agro.cap.ru/UserContent/minselhoz/file/5c4b6f7c-2afb4115-93b1-82d3f8c9e57b/slajdi-k-kollegii.pdf

[13] Petrova, S.Y. The State regulation of agricultural production, taking into consideration foreign countries [Text] / S.Y. Petrova, Frolova O.A. // Bulletin of Altai State University, 2013, № 4, pp. 126-131.

[15] Prokofieva, N.V. On the methodology for assessing the level of the State support for agriculture [Text] / N.V. Prokofieva // Economics of agricultural and processing companies, 2011, № 11, pp. 53-55.

[16] Reisberg, B. On evaluating the effectiveness of government programs [Text] / Economist, 2011, № 7, pp. 19-27.

[17] Polyak, K. The Catalysts for Enterprise Development at the Confluence, On Campus Student Incubator, Binghamton University, 2012, pp. 6-7.

[18] Aleksandr S. Kuznetsov. Russian Professor's meeting. Russian Journal of Physical Education and Sport. Pp. 2019, 14(1), 17-22. DOI: 10.14526/2070-4798-2019-14-1-18-24 